\title{
Erratum to: Stochastic ground-motion simulation of two Himalayan earthquakes: seismic hazard assessment perspective
}

\author{
Ashish Harbindu • Mukat Lal Sharma • Kamal
}

Published online: 23 November 2011

(C) Springer Science+Business Media B.V. 2011

Erratum to: J Seismol (2011)

DOI 10.1007/s10950-011-9247-6

Unfortunately, equation 7 was incorrectly presented.

The corrected version of equation is given below.

$$
G S= \begin{cases}R & R \leq 100 \mathrm{~km} \\ (100 R)^{1 / 2} & R>100 \mathrm{~km}\end{cases}
$$

The online version of the original article can be found at http:// dx.doi.org/10.1007/s10950-011-9247-6.

\footnotetext{
A. Harbindu $\cdot$ M. L. Sharma $(\bowtie)$

Department of Earthquake Engineering, Indian Institute of Technology,

Roorkee, India

e-mail: sharmamukat@gmail.com
}

\section{A. Harbindu}

e-mail: ashish219@gmail.com

Kamal

Department of Earth Sciences, Indian Institute of Technology, Roorkee, India e-mail: kamalfes@iitr.ernet.in 